\title{
Effect of phytase on the water quality of Vietnamese pangasius ponds
}

\author{
Ảnh hưởng của enzyme phytase lên môi trường nước của ao nuôi cá tra Việt Nam \\ LE Xuan Thinh ${ }^{1}$; DANG Xuan Hien ${ }^{1}$; TRUONG Ngoc Trinh ${ }^{2}$ \\ ${ }^{1}$ School of Environmental Science and Technology, Hanoi University of Science and Technology, Hanoi, Vietnam; ${ }^{2}$ College of Aquaculture and Fisheries, \\ Can Tho University, Can Tho city, Vietnam
}

\begin{abstract}
Striped catfish (Pangasianodon hypophthalmus) is freshwater fish that is raising mainly in the Mekong Delta. The research was implemented at the Model Farm (College of Aquaculture and Fisheries), Can Tho University during 6 months from May to November of 2016 and aimed to evaluate the water quality between two treatments of feed in the pangasius production for proposing a better environmental management method. The treatment 1 (control treatment, $\mathrm{CT}$ ) has two ponds used feed without adding phytase and treatment 2 (experiment treatment, ET) includes two ponds used feed with adding phytase. The results showed that the temperature, $\mathrm{pH}, \mathrm{DO}, \mathrm{TSS}, \mathrm{COD}, \mathrm{BOD}, \mathrm{N}-\mathrm{NO}_{2^{-}}, \mathrm{N}-\mathrm{NO}_{3^{-}}$, TKN, TAN were not significantly different $(p>0.05)$ between the CT and ET ponds. At the experiment pond (EP), the

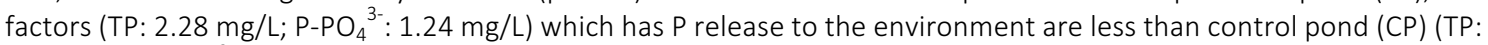

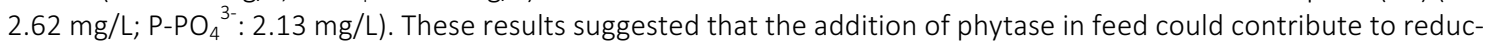
ing the nutrient to the water body of pangasius pond.
\end{abstract}

\begin{abstract}
Cá tra (Pangasianodon hypophthalmus) là loài thủy sản nước ngọt được nuôi chủ yếu ở các tỉnh Đồng bằng sông Cửu Long. Nghiên cứu được thực hiện trong 6 tháng từ tháng 05 -11/2016 tại Trang trại mẫu đặt tại Khoa Thủy sản, Trường Đại học Cần Thơ nhằm đánh giá chất lượng nước giữa 2 nghiệm thức thức ăn trong giai đoạn nuôi cá thịt để đề xuất biện pháp quản lý chất lượng nước ao nuôi tốt hơn. Nghiệm thức 1 (nghiệm thức đối chứng, CT) gồm 2 ao nuôi sử dụng thức ăn không bổ sung enzyme phytase, nghiệm thức 2 (nghiệm thức thí nghiệm, ET) gồm 2 ao nuôi sử dụng thức ăn có bổ sung enzyme phytase. Kết quả thi nghiệm cho thấy giá trị nhiệt độ, pH, DO, TSS, COD, BOD, $\mathrm{H}_{2} \mathrm{~S}, \mathrm{~N}-\mathrm{NO}_{2}{ }^{-}, \mathrm{N}-\mathrm{NO}_{3}$, TKN, TAN ở mức phù hợp cho ao đối chứng (CT). Tại ao thí nghiệm (ET) (TP:2,28 mg/L; $P-P O_{4}{ }^{3-}: 1,24 \mathrm{mg} / \mathrm{L}$ ) lượng $P$ thải ra it hơn so với ao CT (TP: 2,62 mg/L; $P-P O_{4}^{3-}: 2,13 \mathrm{mg} / \mathrm{L}$ ) chứng tỏ việc bổ sung enzyme phytase trong thức ăn đã góp phần làm giảm lượng lân thải ra môi trường nước trong nuôi cá tra.
\end{abstract}

Keywords: catfish, water quality, enzyme phytase

\section{Introduction}

Striped catfish (Pangasianodon hypophthalmus) is a main production sector and high exporting value of Mekong Delta with a yield of 734,880 tons annually and 1.55 billion USD (VASEP, 2016). In recent years, the water quality of pangasius production is warned on pollution due to the huge supply of feed but only part of it was consumed by fish, the rest was discharged to the water environment. According to Cao Van Thich (2008), the striped catfish absorbed only about $43.6 \% \mathrm{~N}, 30.1 \% \mathrm{P}$, the remain $\mathrm{N}, \mathrm{P}$ released to the environment. Nguyen Thi Thanh Truc et al. (2012) also researched on the addition of phytase to feed which helped to increase the growth rate and reduced the Phosphorous $(P)$ in outlet water. However, the research was implemented on a small scale and short time. Therefore, the investigation of water quality between two types of feed was done to propose a good management method for water environment of pangasius production ponds. The research was done at Model Farm in Cai Rang district, Can Tho city under the framework of SUPA project.

\section{Research methodology}

\subsection{Experiment}

The research was implemented from May to November of 2016 in four striped catfish ponds with an average area of $200 \mathrm{~m}^{2}$ for each and $2.5 \mathrm{~m}$ deep. Water was exchanged every day about $30 \%$ each time by pumping from sedimentation pond $\left(3000 \mathrm{~m}^{2}\right)$.

Stock fish was bought at Phu Thuan A commune, Hong Ngu district, Dong Thap province with an average weight is 18 $\mathrm{g} /$ fish and density is about $40 \mathrm{fish} / \mathrm{m}^{2}$. The experiment has two treatments with two replications of each. Control treatment (CT): without using phytase in feed and with using phytase $0.01 \%$ in feed at experiment treatment (ET). 
Phosphorous in the phytase or phytic acid form was not digested by aquatic animals and consequently discharged through faeces caused an environmental pollution. These phosphorous were also the feed sources for bacteria growing and dispersing in water led to an algae bloom and adversely affected to the aquatic species (Sharpley et al., 1995, Mullaney et al., 2000, Satyanarayana, 2001). It needs a phytase enzyme to decompose phytase because aquatic animals cannot synthesize phytase enzyme by themselves. Therefore, this enzyme was added to feed to enhance the digestion effect and adsorption of phosphorous as well as other available nutrients. Adding phytase to feed was not only increasing the assimilation of phosphorous component existing in the feed and adsorption of protein but also reducing the environmental impact (Igbasan et al., 2001).

During the first three months, striped catfish was fed two times per day by feeds size $2 \mathrm{~mm}$, 30\% protein with food portion was about 3-6\% fish weight/day. From the fourth month, it was fed only one time per day with feed contains $26 \%$ protein at size $4-6 \mathrm{~mm}$.

\subsection{Sample collection and analysis method}

Samples were collected at the same point under the feeding bridge where fish were fed at every time. Temperature, $\mathrm{pH}$, DO were directly measured at the ponds. COD: collected to $125 \mathrm{ml}$ glass bottle and pushed under water surface about 10-20 cm, sealed cap under water to avoid air bubble. Fixation by the $\mathrm{H}_{2} \mathrm{SO}_{4} 4 \mathrm{M}$ solution. BOD, TSS, $\mathrm{H}_{2} \mathrm{~S}$, TAN, $\mathrm{P}-\mathrm{PO}_{4}{ }^{3-}, \mathrm{TN}, \mathrm{TP}, \mathrm{N}-\mathrm{NO}_{2}{ }^{-}, \mathrm{N}-\mathrm{NO}_{3}{ }^{-}$: collected in a 1-litre plastic bottle and kept stored in cold preservation box. $\mathrm{H}_{2} \mathrm{~S}$ : collected to $125 \mathrm{ml}$ brown glass bottle and pushed under water surface about $20-30 \mathrm{~cm}$. pH, temperature, and DO were measured every day (at 8 am and 4 pm) by HANNA analyser. Samples of other factors such as COD, BOD, TSS, $\mathrm{H}_{2} \mathrm{~S}, \mathrm{TAN}, \mathrm{P}-\mathrm{PO}_{4}{ }^{3-}, \mathrm{TKN}, \mathrm{TP}, \mathrm{N}-\mathrm{NO}_{2}{ }^{-}, \mathrm{N}-\mathrm{NO}_{3}{ }^{-}$were collected before raising (L1) and every two weeks in the morning time (total 13 times). Water was analysed at Water Quality Laboratory - College of Aquaculture and Fisheries, Can Tho University. Sample reserve and analysis method followed the instruction and standard (APHA et al, 1995).

\subsection{Data analysis method}

Data were analysed and treated in Excel and using ANOVA analysis method by SPSS software with statistic significant $p \leq 0.05$.

\section{Results and discussion}

\subsection{Temperature, pH, DO between control and experiment}

In the control pond $(\mathrm{CP})$, the parameters in morning and afternoon were fluctuated in ranges of temperature 29.3 $33.3^{\circ} \mathrm{C}, \mathrm{pH} 6.8-8.5$, and DO $1.6-8.3 \mathrm{mg} / \mathrm{L}$. In the experiment pond (EP), parameters were also fluctuated in ranges of temperature $29.5-33.1^{\circ} \mathrm{C}, \mathrm{pH} 7.0-8.0$ and DO 2.0-8.5 mg/L.
Generally, the investigated temperature in the ponds was not significantly fluctuated during the production period, the temperature in the mornings was lower than in the afternoons but not exceeded $2^{\circ} \mathrm{C}$. The $\mathrm{pH}$ at the beginning period was always high and reduced at the end of the period, and dissolved oxygen was low in the morning and high at noon due to the photosynthesis of algae. These results were similar to other studies from different authors. Duong Thuy Yen (2003) showed that striped catfish lived in a large range of temperature with maximum $40.8^{\circ} \mathrm{C}$ and minimum $16.7^{\circ} \mathrm{C}$. They can survive in the environment that $\mathrm{pH}$ was lower than 4 and DO was lower than $2 \mathrm{mg} / \mathrm{L}$. Boyd (1998) also mentioned that the optimum conditions for striped catfish development were temperature $28-32^{\circ} \mathrm{C}$, pH 6.0-9.0 and DO 5-10 mg/L. Therefore, temperature, $\mathrm{pH}$, and DO in this research could be the suitable conditions for striped catfish production.

\subsection{Fluctuation of BOD and COD}

The COD value fluctuated at every collected sample in both control pond (CP) and experiment pond (EP) with adding phytase. COD before raising at EP was: $35.5 \pm 1.36 \mathrm{mg} / \mathrm{L}$ and at $C P 23.5 \pm 2.04 \mathrm{mg} / \mathrm{L}(\mathrm{P}>0.05)$ and COD after harvesting at EP was $57.6 \pm 4.53$ and at $C P$ was $20.8 \pm 2.26 \mathrm{mg} / \mathrm{L}$ $(P<0.05)$. At EP, COD fluctuated in $28.8-156 \mathrm{mg} / \mathrm{L}$, the average values of COD in whole period were $62.4 \pm 33.2 \mathrm{mg} / \mathrm{L}$ which were higher than CP (COD 20.8-119 mg/L, the average value was $47.5 \pm 30.6 \mathrm{mg} / \mathrm{L})$. As late to the end of the production period, as more increasing of biomass in the pond because of waste increased from fish which caused a strong oxidation of organics. It led to increasing COD at the end of the period and exceeded the suitable threshold (COD < $150 \mathrm{mg} / \mathrm{L}$ (Vietnamese Standard QCVN 02-20:2014/BNNPTNT)) (Figure 1).

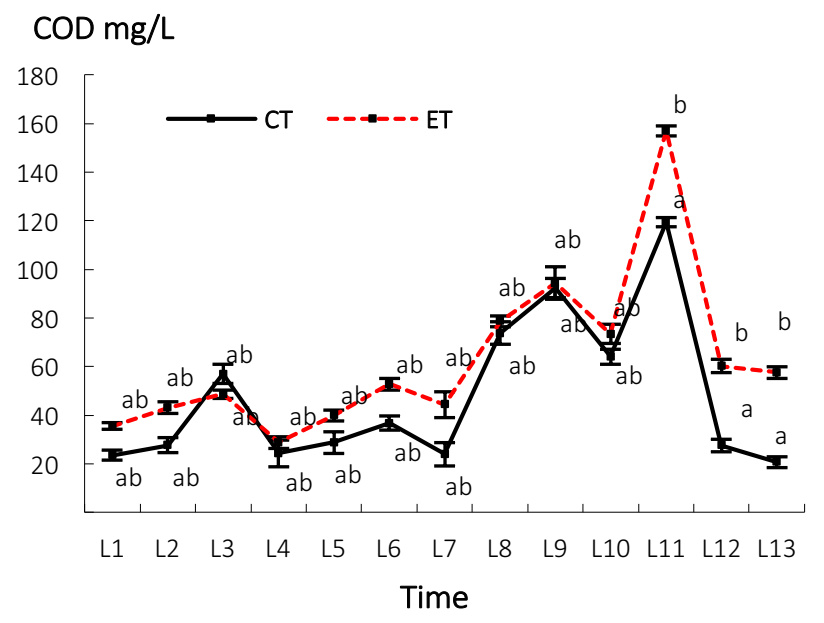

Figure 1. Fluctuation of COD at different times

COD in the EP with adding enzyme phytase had values at different collection samples L11, L12 and L13 are: $157 \pm$ $1.99^{\mathrm{b}} \mathrm{mg} / \mathrm{L} ; 60.2 \pm 2.76^{\mathrm{b}} \mathrm{mg} / \mathrm{L}$ and $57.6 \pm 2.26^{\mathrm{b}} \mathrm{mg} / \mathrm{L}$, higher $(p<0.05)$ than the CP with values such as: $119 \pm$ $1.81^{\mathrm{a}} \mathrm{mg} / \mathrm{L}(\mathrm{L} 11) ; 27.6 \pm 2.47^{\mathrm{a}} \mathrm{mg} / \mathrm{L}(\mathrm{L} 12)$ and $20.8 \pm 2.26^{\mathrm{a}}$ $\mathrm{mg} / \mathrm{L}$ (L13). Fish weight in the EP at sample L13 was 4,948 
$\mathrm{kg}$ and feed consumed till this period was $6,014 \mathrm{~kg}$, meanwhile at the CP fish weight was only 3,283 kg and feed was 4,110 kg. Therefore, wastes in EP higher than CP and COD in EP was also higher than CP.

According to Nguyen Thanh Phuong et al. (2012), the suitable COD value for striped catfish was $15-30 \mathrm{mg} / \mathrm{L}$, and the maximum was $15-40 \mathrm{mg} / \mathrm{L}$. Other authors also gave the same results as a suitable range of COD 10-20 mg/L (Duong Nhut Long, 2005) and 9.6-11.4 mg/L (Cao Van Thich, 2008). Similarly, BOD value (Figure 2) in CP was about 6.26-16.5 $\mathrm{mg} / \mathrm{L}$, average $10.8 \pm 2.96 \mathrm{mg} / \mathrm{L}$; BOD in EP was about 9.0$18.0 \mathrm{mg} / \mathrm{L}$, average $13.7 \pm 2.61 \mathrm{mg} / \mathrm{L}$. The suitable condition of BOD was about 10-20 mg/L (Boyd, 1998). Huynh Truong Giang et al. (2008) asserted that the BOD value at striped catfish production ponds in An Giang was high around 1.9-23 mg/L. Therefore, BOD values in these ponds are still in the suitable range condition for growing of striped catfish.

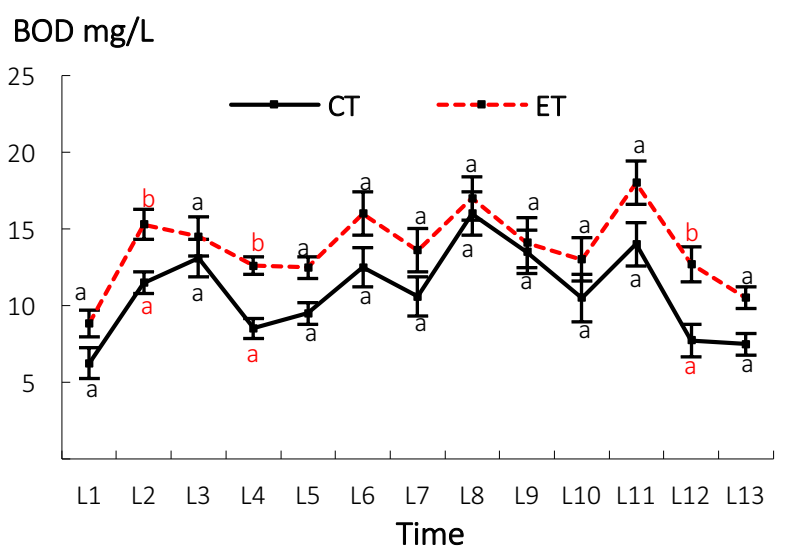

Figure 2. Fluctuation of BOD at different times

\subsection{Fluctuation of TSS}

TSS values have no significant differences between control ponds (CP) and experiment ponds (EP) with adding phytase ( $p>0.05$ ). In CP, TSS values were $26.5-222 \mathrm{mg} / \mathrm{L}$, the average was $118 \pm 60.5 \mathrm{mg} / \mathrm{L}$. In experiment pond, TSS was $35.0-208 \mathrm{mg} / \mathrm{L}$, average $116 \pm 67.0 \mathrm{mg} / \mathrm{L}$. TSS values in this research have a trend of increasing by production time (L1 - L9) (Figure 3).

TSS values were high leading to low purity and vice versa, the suitable value for aquaculture production is lower than $50 \mathrm{mg} / \mathrm{L}$ (Boyd, 1998). In the pond, the surplus feed caused an increase in TSS in the pond and always exceeding the warning threshold value of striped catfish production. These results were similar to the investigation of Dang Van Quoi (2014) with value is $72.3 \pm 33.4 \mathrm{mg} / \mathrm{L}$, in the range 40 $132 \mathrm{mg} / \mathrm{L}$.

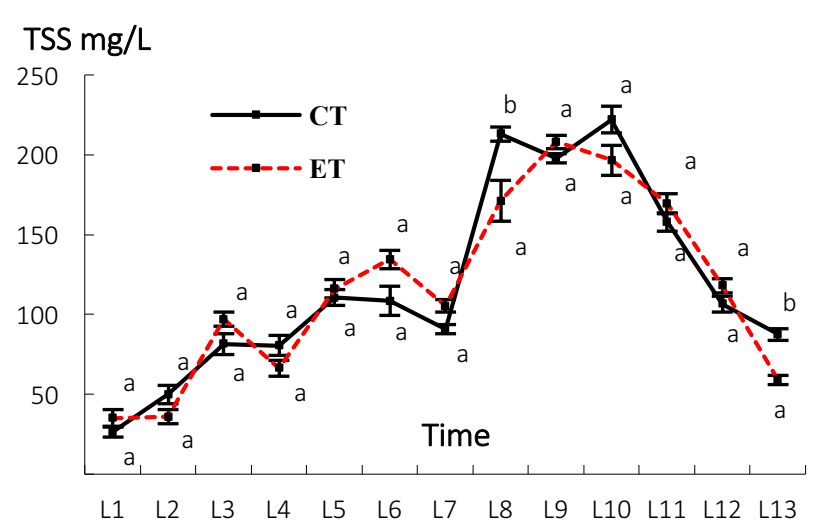

Figure 3. Fluctuation of TSS at different times

\subsection{Fluctuation of TAN, $\mathrm{NH}_{3}$ and $\mathrm{NH}_{4}{ }^{+}$}

TAN values of ponds were shown in Figure 4. In CP, TAN average was $1.78 \pm 0.035 \mathrm{mg} / \mathrm{L}(0.172-3.1 \mathrm{mg} / \mathrm{L})$, and the average value for experiment pond was $1.83 \pm 0.047 \mathrm{mg} / \mathrm{L}$ (0.16-3.04 mg/L). TAN was rapidly increasing from the first to the fifth sample and reducing at the end of the period. These results were also similar to other researches such as Nguyen Thanh Phuong et al. (2012) with TAN in the pond was about 2.86-4.06 $\mathrm{mg} / \mathrm{L}$.

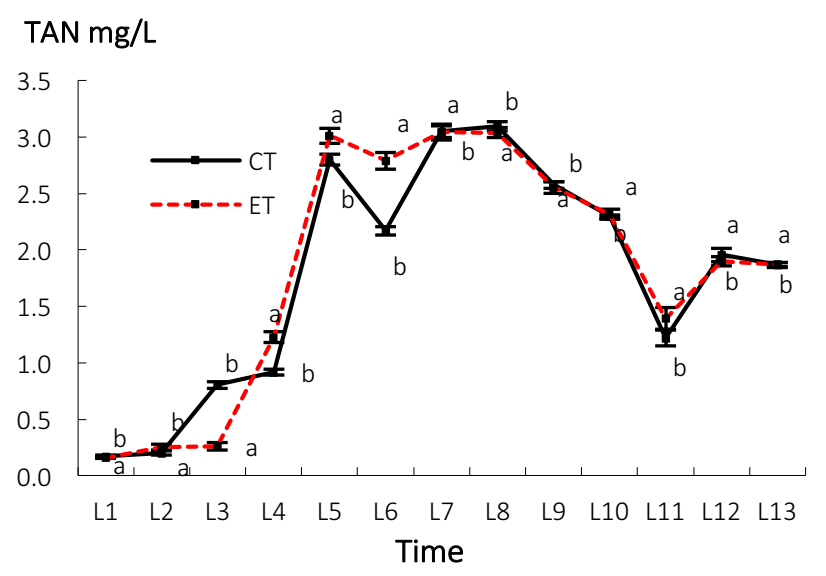

Figure 4. Fluctuation of TAN at different time

TAN is the total value of $\mathrm{NH}_{3}$ and $\mathrm{NH}_{4}{ }^{+}$, in which $\mathrm{NH}_{3}$ is very toxic gas for fish. $\mathrm{NH}_{3}$ in $\mathrm{CP}$ was around 0.005-0.25 mg/L, average $0.043 \pm 0.067 \mathrm{mg} / \mathrm{L}$; in EP was $0.002-0.172 \mathrm{mg} / \mathrm{L}$, average $0.042 \pm 0.050 \mathrm{mg} / \mathrm{L}$. $\mathrm{NH}_{3}$ values were not significantly different $(p>0,05)$ in all samples. According to Huynh Truong Giang et al. (2008), $\mathrm{NH}_{3}<0.02 \mathrm{mg} / \mathrm{L}$ was suitable for aquaculture production. In the pond, the presence of $\mathrm{NH}_{4}{ }^{+}$ will not affect to fish, but at high concentration will cause an algae bloom and poison to fish. In this research, $\mathrm{NH}_{4}{ }^{+}$ was in the range of $0.138-2.97 \mathrm{mg} / \mathrm{L}$; average in the control pond was $1.74 \mathrm{mg} / \mathrm{L}$ and in the experiment pond: 1.84 $\mathrm{mg} / \mathrm{L}$ (Figure $5 \mathrm{~b}$ ). 


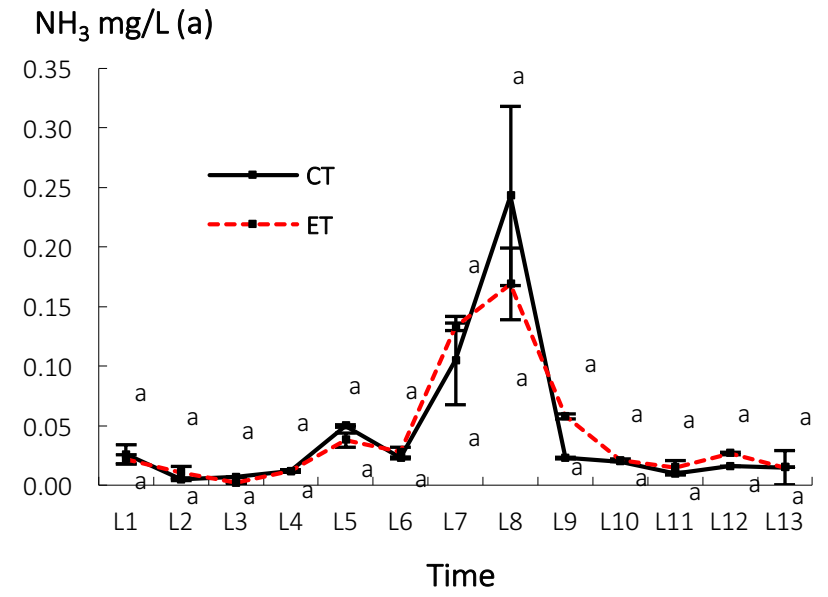

Figure 5a. Fluctuation of $\mathrm{NH}_{3}$ at different times

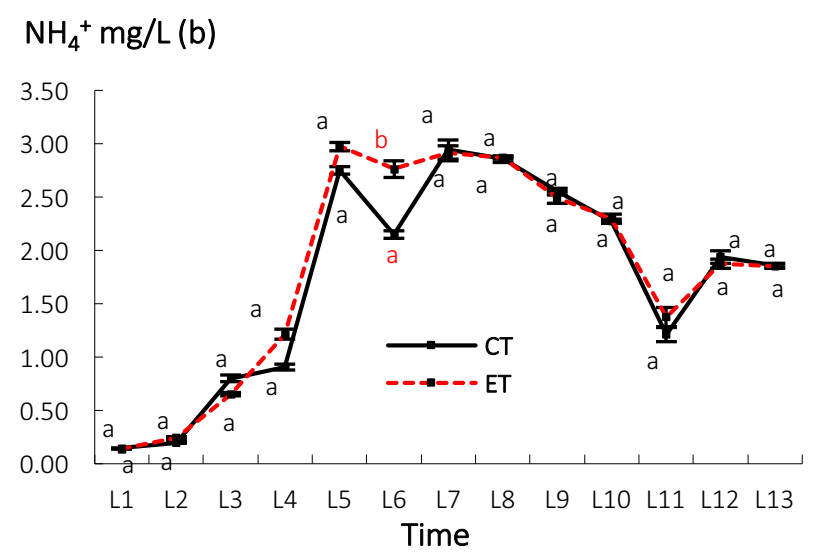

Figure 5b. Fluctuation of $\mathrm{NH}_{4}{ }^{+}$at different times

\subsection{Fluctuation of $\mathrm{N}-\mathrm{NO}_{2}{ }^{-}, \mathrm{N}-\mathrm{NO}_{3}{ }^{-}$and TKN}

The results showed that $\mathrm{N}-\mathrm{NO}_{2}{ }^{-}$concentration in the $\mathrm{CP}$ was around 0.009-0.315 mg/L (average value: $0.108 \pm 0.085$ $\mathrm{mg} / \mathrm{L}$ ), in the EP was $0.012-0.397 \mathrm{mg} / \mathrm{L}$ (average $0.144 \pm$

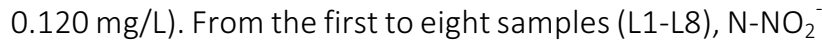
concentration in the $\mathrm{CP}$ and the EP were low and increased to get the highest value in the ninth sample. It was decreased after that to the end of the period. This can be explained that the nitrification needs oxygen for oxidation $\mathrm{NH}_{3}$ to $\mathrm{N}-\mathrm{NO}_{2}{ }^{-}$and from $\mathrm{N}-\mathrm{NO}_{2}{ }^{-}$to $\mathrm{N}-\mathrm{NO}_{3}{ }^{-}$by bacteria (Truong Quoc Phu, 2006) then at the end of the period the low dissolved oxygen led to decreasing of $\mathrm{N}-\mathrm{NO}_{2}{ }^{-}$. However, it shows that the $\mathrm{N}-\mathrm{NO}_{2}{ }^{-}$concentrations are still safe for catfish.

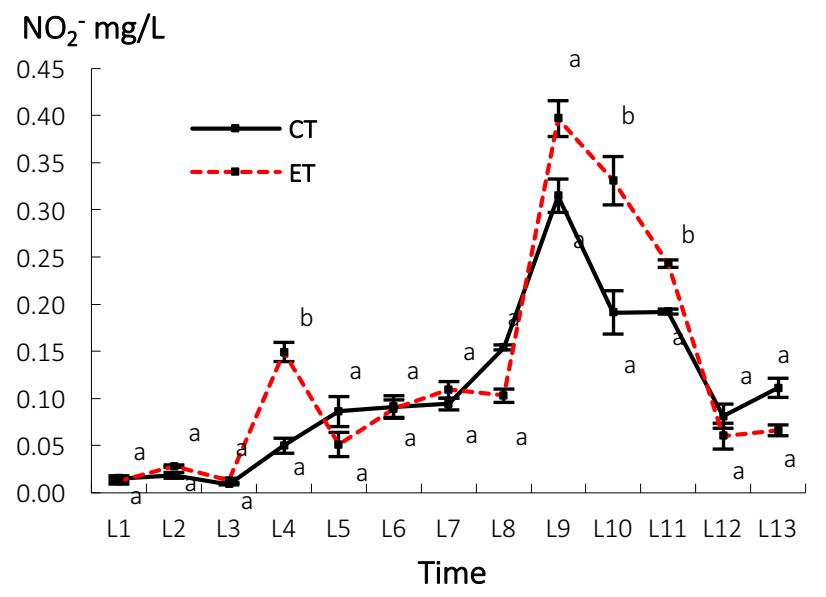

Figure 6. Fluctuation of $\mathrm{N}-\mathrm{NO}_{2}{ }^{-}$at different times

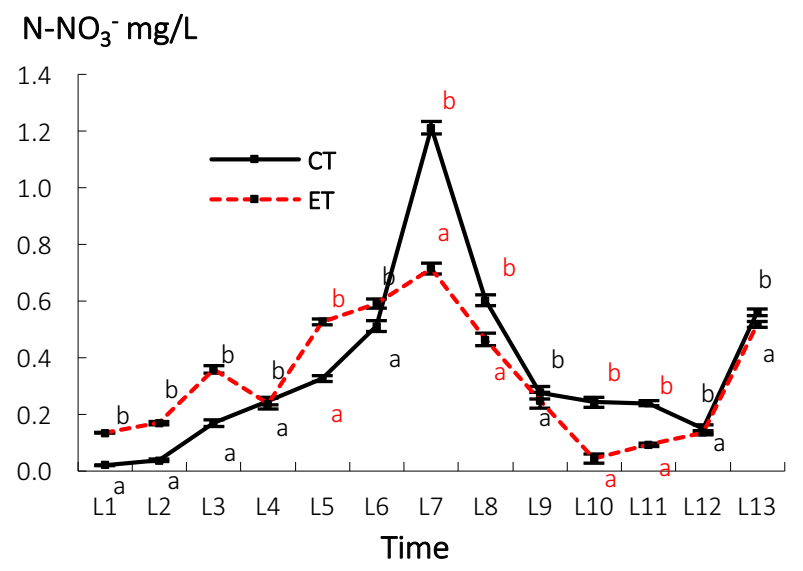

Figure 7. Fluctuation of $\mathrm{N}-\mathrm{NO}_{3}{ }^{-}$at different times

$\mathrm{N}-\mathrm{NO}_{3}{ }^{-}$was produced from the oxidation of $\mathrm{N}-\mathrm{NO}_{2}{ }^{-}$by bacteria, $\mathrm{N}^{-\mathrm{NO}_{3}}{ }^{-}$in the ponds was not toxic but it will affect at high concentration (> $10 \mathrm{mg} / \mathrm{L}$ ) (Boyd, 1998; Le Van Cat et al, 2006). Concentration of $\mathrm{N}^{-N_{3}}{ }_{3}$ in the $\mathrm{CP}$ was around $0.019-1.21 \mathrm{mg} / \mathrm{L}(0.352 \pm 0.309 \mathrm{mg} / \mathrm{L})$, and in the EP was 0.043-0.715 mg/L (0.325 $\pm 0.213 \mathrm{mg} / \mathrm{L}) . \mathrm{N}_{-} \mathrm{NO}_{3}{ }^{-}$concentration was increasing from the first to the seventh and it was decreasing at the end of period (Figure 7). Therefore, $\mathrm{N}$ $\mathrm{NO}_{3}{ }^{-}$concentration has low value and was safe to catfish. In addition, the water exchange and algae adsorption also helped to decrease the nitrate concentration.

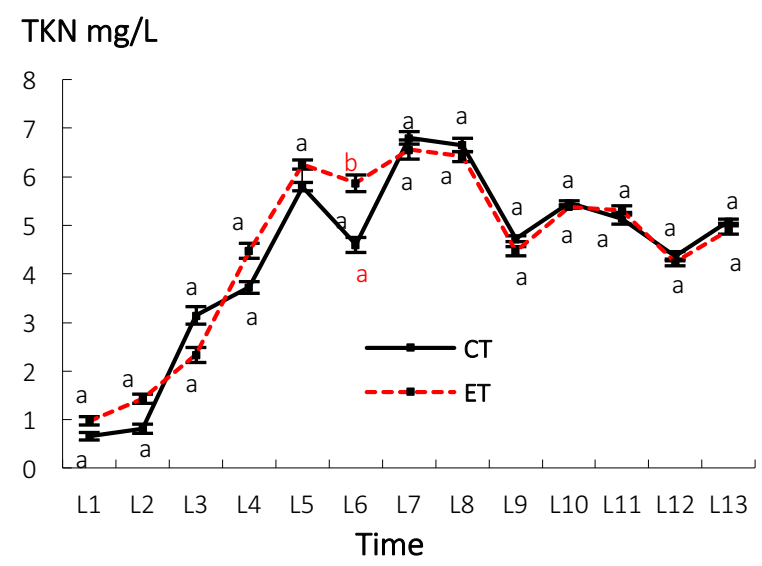

Figure 8 Fluctuation of TKN at different times 
TKN investigation at ponds was shown in Fig 8. In the control pond, the average value TKN was $4.38 \pm 1.88 \mathrm{mg} / \mathrm{L}$ $(0.659-6.79 \mathrm{mg} / \mathrm{L})$ and in the experiment pond was 4.48 \pm 1.84 (0.975-6.55 mg/L). TKN was slightly increasing from the beginning of the period and reached the highest values in the $7^{\text {th }}$ and $8^{\text {th }}$ sample, it then decreased to the end period. These results are the same as the research of Chau Minh Khoi et al. (2012).

\subsection{Fluctuation of P-PO ${ }_{4}^{3-}$ and TP}

Concentration $\mathrm{P}_{-} \mathrm{PO}_{4}{ }^{3-}$ (Fig. 7) shown that it increased from the beginning to the end period in both control and experiment pond. The average value of $\mathrm{P}_{-} \mathrm{PO}_{4}{ }^{3-}$ at the control pond: $1.15 \pm 1.07 \mathrm{mg} / \mathrm{L}$ (fluctuated from $0.045-3.16 \mathrm{mg} / \mathrm{L}$ ) higher than the experiment pond: $0.816 \pm 0.68 \mathrm{mg} / \mathrm{L}$ (fluctuated from $0.07-1.88 \mathrm{mg} / \mathrm{L})(\mathrm{p}>0.05)$. At the first $7 \mathrm{sam}$ ples, the concentration of $\mathrm{P}_{-} \mathrm{PO}_{4}{ }^{3-}$ in the $\mathrm{CP}$ and EP were not significantly different $(p>0.05)$. However, from the $7^{\text {th }}$ sample, the concentration of $\mathrm{P}_{-} \mathrm{PO}_{4}{ }^{3-}$ in the EP was much lower than the CP $(p<0.05)$, especially at the last sample, the concentration $\mathrm{P}_{-} \mathrm{PO}_{4}{ }^{3-}\left(1.64 \pm 0.13^{\mathrm{a}} \mathrm{mg} / \mathrm{L}\right)$ in the EP was much lower than the CP $\left(2.82 \pm 0.14^{\mathrm{b}} \mathrm{mg} / \mathrm{L}\right)$. These results showed that adding enzyme phytase to feed of the EP could cause reducing of phosphate content in comparison with the CP. According to Truong Quoc Phu (2006), concentration $\mathrm{P}_{-} \mathrm{PO}_{4}{ }^{3-}$ recommended for aquaculture was 0.005-2 $\mathrm{mg} / \mathrm{L}$. Concentration $\mathrm{P}_{-} \mathrm{PO}_{4}{ }^{3-}$ investigated at these ponds were higher than recommended but in the striped catfish production, the feed consumed was very high, which caused a high accumulation of waste. Chau Minh Khoi (2012) also given that in An Giang, $\mathrm{P}_{-} \mathrm{PO}_{4}{ }^{3-}$ in the pond had value at $8 \mathrm{mg} / \mathrm{L}$, higher than these research values at $\mathrm{CP}(3.16 \pm 0.12 \mathrm{mg} / \mathrm{L})$ and $\mathrm{EP}(2.02 \pm 0.09 \mathrm{mg} / \mathrm{L})$ but the fish was still alive.

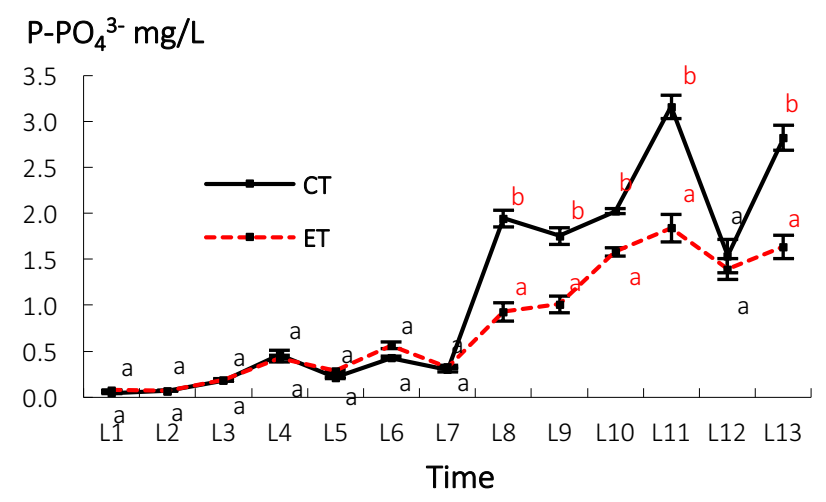

Figure 9. Fluctuation of $\mathrm{PO}_{4}{ }^{3-}$ at different times

The value TP in the control and experiment ponds was increasing, especially from the $8^{\text {th }}$ sample the value of TP in the experiment ponds was significantly lower $(p<0.05)$ than the control ponds. This was clearly shown in the $9^{\text {th }}$ and $13^{\text {th }}$ sample, the concentration of TP at the experiment pond with adding phytase $\left(1.82 \pm 0.12^{\mathrm{a}} \mathrm{mg} / \mathrm{L}\right.$ and $3.14 \pm$ $0.294^{\mathrm{a}} \mathrm{mg} / \mathrm{L}$ ) was much lower than the control pond (3.49 $\pm 0.156^{\mathrm{b}} \mathrm{mg} / \mathrm{L}$ and $\left.3.47 \pm 0.229^{\mathrm{b}} \mathrm{mg} / \mathrm{L}\right)(\mathrm{p}<0.05)$ (Fig 10). Therefore, the addition of phytase to feed created a better result, reduced TP and improved the environmental condition in the production ponds.

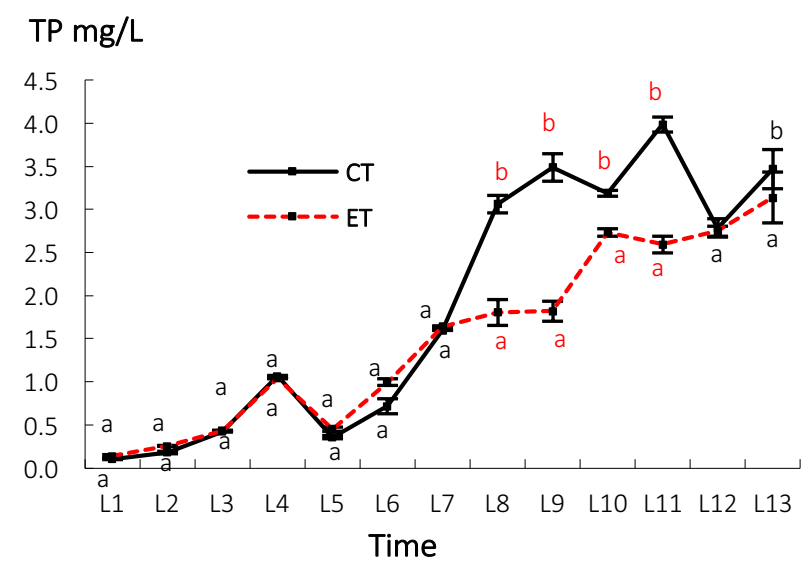

Figure 10. Fluctuation of TP at different times

\section{Conclusion and recommendation}

\subsection{Conclusion}

The physical factors of the water environment $(\mathrm{pH}$, temperature, TSS) and chemical factors (DO, COD, BOD, TAN, $\mathrm{H}_{2} \mathrm{~S}, \mathrm{~N}-\mathrm{NO}_{2}{ }^{-}, \mathrm{N}-\mathrm{NO}_{3}{ }^{-}, \mathrm{TKN}$ ) was suitable to striped catfish production and there were no significant differences between the control and the experiment pond.

The average values of $\mathrm{P}-\mathrm{PO}_{4}{ }^{3-}$, TP were $0.816 \mathrm{mg} / \mathrm{L} ; 1.52$ $\mathrm{mg} / \mathrm{L}$ at the experiment pond and $1.15 \mathrm{mg} / \mathrm{L} ; 1.88$ at the control pond. These values at the experiment pond were lower than the control pond but still in the suitable range for striped catfish production. The addition of phytase enzyme helped to reduce the phosphate in the striped catfish production ponds.

\subsection{Recommendation}

The research needs to replicate more at each experiment for clear recognition of the effect of phytase enzyme to the environmental water factors in the striped catfish production ponds.

\section{References}

[1] Boyd, C.E., 1998. Water Quality for Ponds Aquaculture. Research and Development series No. 43, August 1998, Alapama, 37pp.

[2] Cao Van Thich, 2008. Water quality and nutrient accumulation in the pangasius pond (Pangasianodon hypophthalmus) in O Mon district, Can Tho city. Master thesis in Aquaculture. Can Tho University. Vietnam.

[3] Chau Minh Khoi, Hua Hong Nha, Chau Thi Nhien, 2012. Accumulation of nitrate, inorganic phosphate and organic phosphate in water and sludge of pangasius production culture ponds in the Mekong Delta. Journal of Science of Can Tho University, 22a: 17 - 24. 
[4] Dang Van Quoi, 2014. Survey in water quality and growth of production culture pangasius (Pangasianodon hypophthalmus) ponds with and without aeration. Master thesis of aquaculture, Can Tho University, Can Tho, Vietnam.

[5] Duong Thuy Yen, 2003. Survey in some characteristics, formation, growth and physiology of Basa (Pangasius bocourti), Tra (Pangasianodon hypophthalmus) and their hybrid. Master thesis, Can Tho University, Can Tho, Vietnam.

[6] Huynh Truong Giang, Vu Ngoc Ut, and Nguyen Thanh Phuong, 2008. Fluctuation of environmental factors in pangasius (Pangasianodon hypophthalmus) production culture pond in An Giang. Journal of Science of Can Tho University, 1: 1-9.

[7] Igbasan F. A., Männer K., Miksch G., Borriss R., Farouk A., Simon O., 2000. Comparative studies on the in vitro properties of phytases from various microbial origins. Archives of Animal Nutrition, 53(4): 353-373.

[8] Le Bao Ngoc, 2004. Assessment of environmental quality for pangasius production culture ponds in Tan Loc commune, Thot Not district, Can Tho province. Master thesis of environmental science, Can Tho University, Can Tho, Vietnam.

[9] Le Van Cat, Do Hong Nhung, and Ngo Ngoc Cat, 2006. Water for Aquaculture - Quality and Solutions for quality improvement. Science and Technology Press of Hanoi. 414p.

[10] Le Xuan Thinh. Dang Xuan Hien. Truong Ngoc Trinh. Evaluating the addition of enzyme phytase to feed consumption efficiency and phosphorous concentration in the outlet water and sludge of pangasius pond. The 10th Regional Conference on Environmental Engineering 2017 (RC EnE 2017). ISBN 987-604-950308-5. Oct 2017.

[11] Mullaney E. J., Daly C. B., Sethumadhavan K., Rodriquez E., Lei X. G., Ullah A. H., 2000. Phytase activity in Aspergillus fumigatus isolates. Biochemical and $\mathrm{Bi}$ ophysical Research Communication. 275: 759-763.

[12] Nguyen Huu Loc, 2008. Modification of water quality in the pangasius (Pangasianodon hypophthalmus) production culture system at the different. Master thesis of aquaculture, Can Tho University.

[13] Nguyen Thanh Phuong, Tran Ngoc Hai, Duong Nhut Long, and Vo Nam Son, 2012. Lecture of aquaculture production. Can Tho University Press. 152p.

[14] Nguyen Thi Thanh Truc, Nguyen Huy Lam, Vo Thi Thanh Binh, and Le Thanh Hung, 2012. Demonstration of adding phytase from Bacillus subtilus $\mathrm{Ba} 58$ to feed and its effect on feed efficiency and growth of pangasius (Pangasianodon hypophthalmus). Faculty of Aquaculture, Nong Lam University of Hochiminh city, Hochiminh city.

[15] Pham Quoc Nguyen, Le Hong Y, Nguyen Van Cong, and Truong Quoc Phu, 2014. Development of some water factors in the pangasius (Pangasianodon hypophthalmus) production culture ponds. Journal of Science of Can Tho University, 34: 128-136.

[16] Pham Quoc Nguyen, Nguyen Thi Ngoc yen, Truong Quoc Phu, Nguyen Van Cong, 2015. Influence of total ammoniac on pangasius growth (Pangasianodon hypophthalmus). Journal of Science of Hochiminh Education University, 5(70): 168-180.

[17] Satyanarayana T. Phytase production by the yeast, Pichia anomala. Biotechnology Letters. 23: 551-554.

[18] Sharpley N. A, Robinson J. S., Smith S. J., 1995. Bioavailable phosphorus dynamics in agricultural soils and effects on water quality. Geoderma, 67(1-2): 1-15.

[19] Truong Quoc Phu, 2006. Lecture of quality management in aquaculture. Faculty of Aquaculture. Can Tho University, Can Tho, Vietnam.

[20] Vietnam Association of Seafood Exporters and Producers (VASEP), 2016. Export Trend Report. 